\title{
T-Cell Receptor Gene Rearrangement
}

National Cancer Institute

\section{Source}

National Cancer Institute. T-Cell Receptor Gene Rearrangement. NCI Thesaurus. Code C153517.

A molecular abnormality indicating rearrangement of a T-cell receptor (TCR) family gene. 